\title{
Evaluation of The Distance Learning System Success of Apparatus Training: User Satisfaction Mediation
}

\author{
Azwar \\ Universitas Terbuka, Indonesia \\ Sekolah Tinggi Ilmu Islam dan Bahasa Arab (STIBA) Makassar, Indonesia \\ Email: azwar.iskandar@gmail.com \\ Siti Aisyah \\ Universitas Terbuka, Indonesia \\ Email: aisyah@ecampus.ac.id \\ Adji Suradji Muhammad \\ Universitas Maritim Raja Ali Haji, Indonesia \\ Email: suradji@umrah.ac.id
}

\begin{abstract}
This research aims to find out the influence of system quality and service quality of distance learning system on user satisfaction and the achievement of learning outcomes of trainees during the covid-19 pandemic era at the Financial Education and Training Agency of Makassar. In addition, the study also aims to examine how the role of user satisfaction in mediating the influence of system quality and service quality of distance learning systems on learning outcomes. This study used data obtained from respondents through questionnaires and quantitative approaches through component or variant-based of Structural Equation Modelling (SEM) techniques with Partial Least Square (PLS).

The results show that in general the distance learning system has fully run well and successfully based on indicators of DeLone and McLean model. The system quality significantly has positive influence on user satisfaction, service quality significantly has positive influence on user satisfaction and user satisfaction also significantly has positive influence the learning outcomes. Meanwhile, user satisfaction can be a mediator in strengthening the influence of system quality service quality on learning outcomes. Financial Education and Training Agency of Makassar is expected to maintain and improve the quality of systems and services in the existing distance learning system in order to maintain and improve the satisfaction of trainees and learning outcomes.
\end{abstract}

Keywords: system quality, service quality, user satisfaction, learning outcomes, distance learning system

Received: 8 November 2021 ;

Accepted: 30 December 2021;

Publish: December 2021. 


\section{How to Cite:}

Azwar, et.al. (2021). Evaluation of The Distance Learning System Success of Apparatus Training: User Satisfaction Mediation. International Journal of Human Capital Management, 5 (2), 104-119. https://doi.org/10.21009/IJHCM.05.02.10

\section{INTRODUCTION}

In carrying out its duties and functions, namely managing education, training (learning), certification and knowledge management, in the event of a Covid-19 pandemic, Financial Education and Training Agency of Makassar innovates and adapts to services provided through digital platforms and information technology systems of the Kemenkeu Learning Centre (KLC) and Zoom Virtual Meeting (Iskandar and Subekan, 2020; BPPK, 2020). Through this service, the Financial Education and Training Agency of Makassar develops and implements learning in the form of distance learning or Pembelajaran Jarak Jauh (PJJ) as an alternative to learning in order to meet the needs of improving and developing Human Resources (HR) in the Ministry of Finance despite being constrained by restrictions on the implementation of training such as in the pandemic period (Marlena et al., 2018; Nugroho \& Lestyowati, 2020; Yang et al., 2012).

PJJ in Financial Education and Training Agency of Makassar is implemented through the website-based of Kemenkeu Learning Centre (KLC) system (www.klc.kemenkeu.go.id) for NonFace-to-Face sessions, Zoom Virtual Meeting application and the like for Face-to-Face sessions, and Google Form application and the like for training sessions, assignments, and exams (evaluation). The PJJ model is a merger of synchronous and asynchronous learning models. This synchronous model in PJJ is carried out through the Zoom Virtual Meeting application where trainees and trainers/instructors interact simultaneously through the application (Narayana, 2016; Iskandar \& Subekan, 2020; Darmawan, 2018; Nana \& Surahman, 2019). While the asynchronous model in PJJ is carried out through the KLC system where learning is centered on trainees with a self-learning approach through the utilization of online learning resources needed in the system (Iskandar \& Subekan, 2020; Elyas, 2018).

Distance learning at Financial Education and Training Agency of Makassar is an electronic system-based learning process, where the benefits obtained are improving self-learning skills and the ability to display information with the help of information technology devices or systems. However, it cannot be denied, an information technology system always has two sides, namely advantages and disadvantages. Distance learning also has weaknesses or negatives where not all teachers and trainees have the same level of understanding of the operation of system devices and the existence of internet network problems (Syah and Angellia, 2020). Based on the data of the evaluation report on the implementation of PJJ in 2020, there were problems related to the learning system used (Seksi Evaluasi dan Informasi, Balai Diklat Keuangan Makassar, 2020). Of the four types of PJJ randomly selected in the report, it is known that the implementation of distance learning at the Financial Education and Training Agency of Makassar still faces problems related to the quality of the system, the quality of services, both organizers and teachers, and user satisfaction of the distance learning system held. Problems related to this learning system are feared to affect user satisfaction and hinder the achievement of learning outcomes as expected. Therefore, it is necessary to see how successful the implementation of the distance learning system is by analyzing the influence of system quality and service quality on user satisfaction oh thesystem and learning outcomes of training participants.

One popular model that is widely used in researching behavioral aspects in the implementation of an information system, especially the implementation at the organizational level, is the model developed by DeLone and McLean (1992) known as the DeLone and McLean Information System Success Model. This model reflects the dependence of six measurements of 
information system success, namely system quality, information quality, user satisfaction (user statisfaction), use, individual impact and organizational impact. Then, from the contribution of previous research and due to changes in the role and handling of information systems that have developed, DeLone and McLean (2003) updated the model and called it the Updated DeLone and McLean Information System Success Model. DeLone and McLean added one new dimension to the updated model: service quality. Another change found in the updated model is the unification of individual impact and organizational impact into one variable: net benefits (Figure 1).

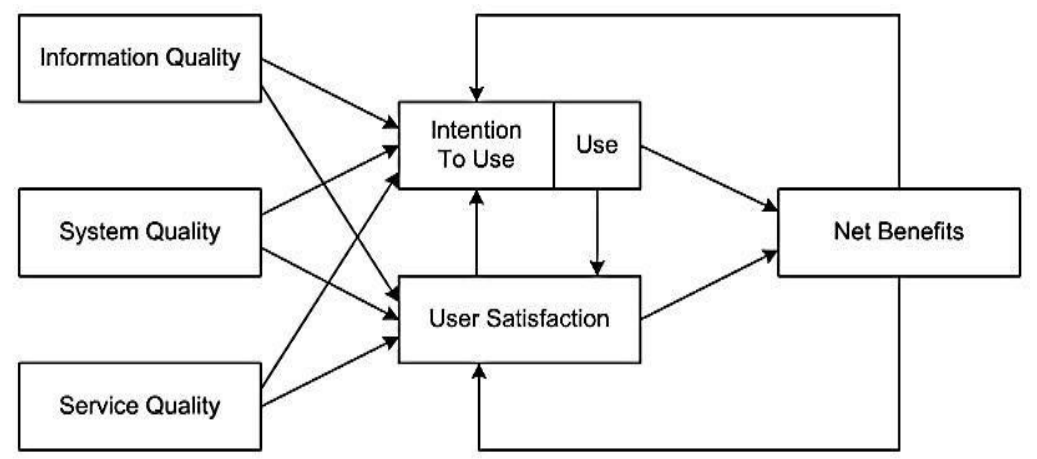

Figure 1

The Updated DeLone and McLean Information System Success Model (2003) Source: DeLone dan McLean (2003)

Given that this distance learning model is a new adaptation or innovation in the Financial Education and Training Agency of Makassar, especially in the pandemic or the new normal era and there are still various problems related to the system based on the evaluation report of learning implementation, it is important to conduct a study or evaluation to see the extent of the success of the implementation of this distance learning system by analyzing the factors that affect the learning system. hi user satisfaction and learning outcomes in distance training during the Covid-19 pandemic, such as system quality and service quality factors.

Previous studies that tested the implementation of distance learning also found problems related to system quality, service quality and user satisfaction. Fahirah, Puteri and Arnesia (2020) found that the use of distance learning systems through Google Classroom during the pandemic is still considered unable to meet the needs of users where the system needs to be equipped with features of overall evaluation of tasks so that student progress can be seen from the assessment of one material to another. Hidayatullah, et al. (2020) found that although the use of virtual meeting zoom system applications became the most commonly used application in the distance learning process, this application system is considered still unable to guarantee the security of its users' data and information. Furthermore, Yulianto (2020) stated that the use of distance learning system with e-Milea system for employees of the Ministry of Marine Affairs and Fisheries in the pandemic period is a relatively new system and there has been no evaluation related to the level of user satisfaction so it is necessary to be evaluated.

Although some of these studies have tried to review and evaluate the implementation of distance learning, they have not reviewed or evaluated the implementation of distance learning implemented specifically for the State Civil Apparatus (Apatarur Sipil Negara, ASN) in pandemic times, especially within the Ministry of Finance. In addition, given that user satisfaction is a very important thing in determining learning outcomes, it is felt necessary to look further at how the role of user satisfaction in mediating the influence of system quality and service quality of distance learning system on learning outcomes, which has not been discussed in previous studies.

Therefore, to fill the gap, this study was conducted with the aim to find out the influence of system quality and service quality of distance learning systems on user satisfaction and the achievement of learning outcomes of trainees during the covid-19 pandemic at the Financial 
Education and Training Agency of Makassar. In addition, the study also aims to examine how the role of user satisfaction in mediating the influence of system quality and service quality of distance learning systems on learning outcomes.

\section{Research Framework and Hypothesis Development}

This study adapts the success model of the information system by DeLone and McLean (2003) which addresses the factors that affect user satisfaction of the information system in public sector organizations and the effect of that satisfaction on the individual performance of its users. Based on an existing literature review, the research framework can be described as follows:

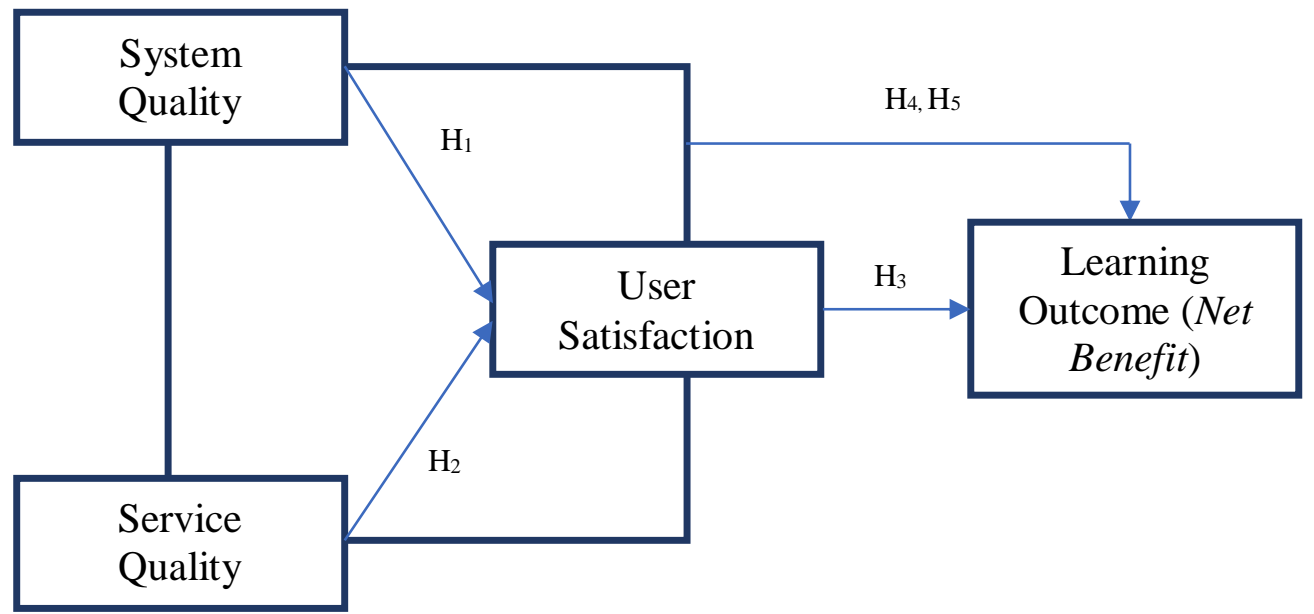

Figure 2

Research Framework

In the research framework above, the quality of the system reflects the characteristics inherent in the system in question in order to generate information. DeLone and McLean (2003) mention that system quality is a combined measure of the performance of hardware and software in an information system. If the quality of the system according to user perception meets good criteria, system users will tend to feel satisfied with the system. Parasuraman, et al. (1988) define service quality as a comparison between customer expectations and the perception of the services they actually receive. In this case, the improved quality of service from the organizers and trainers will have a positive and significant effect on the satisfaction of learning participants. Furthermore, if learning participants feel satisfied with the system, they will tend to feel that the use of the learning system will support the improvement of knowledge and skills. Given that user satisfaction is very important in determining learning outcomes, user satisfaction should be able to mediate the influence of system quality, information quality, and quality of distance learning system services on learning outcomes (Almutairi, 2001).

Based on the description above, the research hypothesis in this study is detailed as follows:

$\mathrm{H}_{1}$ : The system quality of distance learning systems has a positive and significant effect on user satisfaction.

$\mathrm{H}_{2}$ : The service quality of distance learning systems has a positive and significant effect on user satisfaction.

$\mathrm{H}_{3}$ : The user satisfaction of distance learning systems has a positive and significant effect on learning outcome of trainees (net benefit).

$\mathrm{H}_{4}$ : The user satisfaction mediates the influence of the system quality of distance learning systems on the learning outcomes of trainees (net benefit).

$\mathrm{H}_{5}$ : The user satisfaction mediates the influence of the service quality of distance learning systems on the learning outcomes of trainees (net benefit). 


\section{METHODOLOGY}

Based on the objectives to be achieved, this study falls into the category of explanatory research, which aims to explain the relationship between two or more variables (Hamdi \& Ismaryati, 2019) or research that is based on theories or hypotheses that will be used to test a phenomenon that occurs. While in terms of approach, this research uses quantitative approaches through the technique of econometric models or differential statistics (John, 2013; Sarwono, 2006).

The population in this study was all PJJ participants held at the Financial Education and Training Agency of Makassar during the 2020 pandemic which amounted to 348 people. The samples in this study were taken using the nonprobability sampling method, where each member of the population does not have the same opportunity to be selected as a sample (Hamdi and Ismaryati, 2019), with purposive sampling techniques, namely the selection of samples based on certain criteria and considerations (Ghozali, 2011). This sampling technique was chosen because the study population does not have a homogeneous character, so the random sampling technique cannot be used (Ghozali, 2011). Not all PJJ held, hold final/ comprehensive examinations as a measure of learning outcomes. Therefore, PJJs which does not hold a final/comprehensive examinations, can not be measured learning results cognitively, so participants in the PJJs can not be used as a sample. Based on this, the number of research samples was determined as many as 169 people, consisting of: 20 participants of PJJ BMN Management for Goods Users, 30 participants of PJJ Customs Narcotics Team (CNT) I, 30 participants of PJJ Customs Narcotics Team (CNT) II, 29 participants of PJJ Supervision of Passenger Goods, 30 participants of PJJ Head of Customs and Excise Hangar, and 30 participants of PJJ Tax Extension.

The data sources used are primary and secondary data. Primary data is obtained directly from respondents, in the form of answer questions on questionnaire sheets from trainees as respondents. While secondary data was obtained from related agencies such as the Program Reference Framework (Kerangka Acuan Program, KAP) of Training, Outlines of Learning Programs (Garis Besar Program Pembelajaran, GBPP), results of Identicalization of Training Needs (Identifikasi Kebutuhan Diklat, IKD), and Training Organizing Report form Evaluation and Information Section of Financial Education and Training Agency of Makassar.

Based on the research framework (Figure 2), the study used four variables from the DeLone and McLean Information System Success Model (2003). These variables consist of exogenous variables and endogenous variables. Exogenous variables are independent variables that affect dependent variables that are indicated by the presence of arrows derived from those variables to endogenous variables in the model. Meanwhile, endogenous variables are dependent variables that are influenced by independent variables that are indicated by the presence of arrows that go to those variables in the model. The exogenous variables of this study consist of system quality and service quality. Meanwhile, the endogenous variables of this study consist of user satisfaction and learning outcomes (net benefits). In addition, the study also used user satisfaction variables as intervening variables to measure the role of user satisfaction in mediating the influence of system quality and service quality to learning outcomes (net benefit). The operational definitions, descriptions and indicators of each of these variables are spelled out in Table 1. 
Table 1

\section{Research Variables}

\begin{tabular}{|c|c|c|c|c|}
\hline No. & Variables & Descriptions & Indicators & Scale of Measurement \\
\hline 1 & $\begin{array}{l}\text { System Quality } \\
\text { (X1) }\end{array}$ & $\begin{array}{l}\text { The characteristics } \\
\text { inherent in a PJJ } \\
\text { learning system in } \\
\text { order to generate } \\
\text { information, as a } \\
\text { result of a } \\
\text { combination of } \\
\text { hardware and } \\
\text { software performance } \\
\text { present in a PJJ } \\
\text { learning system, } \\
\text { according to user } \\
\text { perception. }\end{array}$ & $\begin{array}{l}\text { This variable is measured using } \\
\text { indicators, namely: (1) the } \\
\text { suitability of learning methods } \\
\text { with pjj material; (2) the } \\
\text { adequacy of the time of pjj } \\
\text { implementation with the amount } \\
\text { of material provided; (3) } \\
\text { adequacy of time in assignments, } \\
\text { quizzes or exams; (4) the } \\
\text { conformity of learning materials } \\
\text { with the expectations/needs of } \\
\text { participants; (5) teaching } \\
\text { materials are easy to understand. } \\
\text { These indicators were adopted } \\
\text { from research indicators of Bailey } \\
\text { and Pearson (1983) include } \\
\text { response time, system flexibility, } \\
\text { conformity, accuracy and } \\
\text { understandability. }\end{array}$ & $\begin{array}{l}\text { 5-point Likert Scale, } \\
\text { namely: Not Good (1); } \\
\text { Less Good (2); Enough } \\
\text { (3); Good (4); Very } \\
\text { Good (5). }\end{array}$ \\
\hline 2. & $\begin{array}{l}\text { Service Quality } \\
\text { (X2) }\end{array}$ & $\begin{array}{l}\text { Assistance and } \\
\text { support services } \\
\text { provided by } \\
\text { organizers and } \\
\text { teachers are actually } \\
\text { received during the } \\
\text { learning, according to } \\
\text { user perception. }\end{array}$ & $\begin{array}{l}\text { This variable is measured using } \\
\text { indicators, namely: } \\
\text { (1) the readiness of the organizer } \\
\text { in serving participants during the } \\
\text { PJJ (responsiveness) process; (2) } \\
\text { good attitude of the organizer in } \\
\text { serving participants during the } \\
\text { PJJ process (assurance); (3) } \\
\text { empathy from the service officer } \\
\text { during the PJJ process (emphaty); } \\
\text { (4) the ability or reliability of } \\
\text { teachers in providing guidance } \\
\text { remotely (reliability); (5) teaching } \\
\text { support in the PJJ process } \\
\text { (tangibles). } \\
\text { These indicators were adopted } \\
\text { from the research indicators of } \\
\text { Parasuraman et al. (1988) include } \\
\text { responsiveness, assurance, } \\
\text { empathy, reliability and tangibles. }\end{array}$ & $\begin{array}{l}\text { 5-point Likert Scale, } \\
\text { namely: Not Good (1); } \\
\text { Less Good (2); Enough } \\
\text { (3); Good (4); Very } \\
\text { Good (5). }\end{array}$ \\
\hline 3. & $\begin{array}{l}\text { User } \\
\text { Satisfaction } \\
\text { (Y1) }\end{array}$ & $\begin{array}{l}\text { Satisfaction on the } \\
\text { ease and usability of } \\
\text { learning facilities, } \\
\text { according to user } \\
\text { perception. }\end{array}$ & $\begin{array}{l}\text { This variable is measured using } \\
\text { indicators, namely: (1) } \\
\text { satisfaction with PJJ facilities that } \\
\text { are easily accessible; (2) } \\
\text { satisfaction with PJJ facilities that } \\
\text { are easy to use. } \\
\text { These indicators were adopted } \\
\text { from research indicators of } \\
\text { Seddon dan Yip (1992) include } \\
\text { system easiness and overall } \\
\text { satisfaction. }\end{array}$ & $\begin{array}{l}\text { 5-point Likert Scale, } \\
\text { namely: Not Good (1); } \\
\text { Less Good (2); Enough } \\
\text { (3); Good (4); Very } \\
\text { Good (5). }\end{array}$ \\
\hline
\end{tabular}




\begin{tabular}{|c|c|c|c|c|}
\hline 4. & $\begin{array}{l}\text { Learning } \\
\text { Outcome (Net } \\
\text { Benefit) (Y2) }\end{array}$ & $\begin{array}{l}\text { The results of the } \\
\text { final/comprehensive } \\
\text { examination of } \\
\text { trainees as a } \\
\text { measurement of the } \\
\text { increase in knowledge } \\
\text { and skills (cognitive) } \\
\text { participants that have } \\
\text { an impact on } \\
\text { individual } \\
\text { performance in the } \\
\text { form of increased } \\
\text { productivity, ease and } \\
\text { speed of work } \\
\text { completion, improved } \\
\text { work performance } \\
\text { and effectiveness of } \\
\text { decision making. }\end{array}$ & $\begin{array}{l}\text { This variable is measured using } \\
\text { indicators, namely the final score } \\
\text { of the participants' comprehensive } \\
\text { examination after taking the } \\
\text { learning as an indicator of the } \\
\text { results/achievements of learning } \\
\text { and individual performance. } \\
\text { This indicator was adopted from } \\
\text { research indicator of Segars and } \\
\text { Grover (1993), manely } \\
\text { effectiveness. }\end{array}$ & $\begin{array}{l}\text { Ordinal scale, namely: } \\
\text { Very Good (4); Good } \\
\text { (3); Enough (2); Less } \\
\text { (1). }\end{array}$ \\
\hline
\end{tabular}

Research models based on the above research framework are analyzed with Structural Equation Modeling (SEM) techniques based on components or variants (component based) or Partial Least Square (PLS) with the SmartPLS program (Ghozali, 2008). This technique was chosen because PLS techniques do not require many assumptions. The data does not have to be normal multivariate distribution and the number of samples does not have to be large (30-100) IGozali, 2008). In addition, this technique is widely used for causal-predictive analysis and is a suitable technique for use in the application of prediction and theory development as in this study. In addition, considering the number of samples used in this study is relatively small then PLS is used as an analysis tool (Hartono, 2011). PLS techniques in this study apply two types of testing to causal models, namely: measurement model testing and structural model testing.

First, measurement model is an assessment of the reliability and validity of a research variable or defined as the relationship between an indicator and a latent variable. The criteria for assessing measurement models in this study are:

a. Convergent validity of the measurement model with reflexive indicators is assessed based on the correlation between the item score/component score with construct score calculated with PLS. Convergent validity aims to determine the validity of any relationship between an indicator and its latent variables. Convergent validity is assessed based on the correlation between item scores and variable scores. The loading value has a high validity rate if it is greater than 0.5 . Loading values smaller than 0.5 will be eliminated (dropped) in the model and re-estimated (Ghozali, 2008).

b. Discriminant validity is used to prove that latent constructs predict the size on their blocks better than the sizes on other blocks. Ghozali (2008) says that the method for measuring discriminant validity is to look at the average variance extracted (AVE) value. If the AVE value of each construct is greater than 0.5 then the model is said to have a good discriminant validity value.

c. Construct reliability (composite reliability) of the indicator block that measures a construct can be evaluated by two measures: internal consistency and Cronbach's Alpha. Ghozali (2008) states that a latent variable has high reliability when the composite reliability value is above 0.7 and Conbach's Alpha is above 0.6.

Second, assess or evaluate structural model. It is performed to look at the relationship between constructs or latent variables, as seen from the estimated value of its structural path coefficients and the R-Square (R2) value of the research model. The estimated value of the structural path coefficients in the model (estimate for path coefficients) is the path coefisen value that indicates the magnitude of the variable's influence (construct). This estimation value is 
evaluated using a t-statistical test obtained through the bootstrapping procedure (Ghozali, 2008). Bootstrapping is a computer-based method used for measuring the accuracy of statistical estimates (statistical quantity and confidence interval) and is an inferential nonparametric technique. The application of the resampling method in bootstrapping allows the enactment of free distributed data, does not require normal distribution assumptions, and does not require large samples (recommended minimum sample of 30). The test is done with a t-statistical test (t-test), with the criteria if obtained a $\mathrm{p}$-value value $\leq 0.05$ (alpha $=5 \%$ ), then concluded significant and vice versa. While the value of R-Square (R2) is the coefficient of determination in endogenous constructs. The coefficient of determination is defined as how much the ability of all exogenous variables in explaining the variance of their endogenous variables. According to Chin (1998), R-Square values are 0.67 (strong), 0.33 (moderate) and 0.19 (weak).

\section{RESULTS AND DISCUSSION}

\section{Response Rate}

The number of research samples of this study amounted to 169 people. The research questionnaire has been sent online to all respondents via their respective email addresses using the evaluation system on Semantik BPPK Applications and Google Forms. Until the final deadline for the return of the questionnaire, the number of questionnaires returned in a complete state and can be further processed only as many as 163 questionnaires. This means that the response rate of the questionnaire reaches $96.45 \%$ of the specified sample number. Although the response rate does not reach $100 \%$, research can still proceed to the analysis stage. Hartono (2011) said that the response rate does not have to reach $100 \%$, but it will be better if the response rate is higher. Even questionnaires sent through the media (such as posts or e-mails) with a response rate of $30 \%$ can be said to be adequate. The questionnaire is then tabulated and processed data.

\section{Analysis Result}

\section{Measurement Model Testing}

Analysis of research data begins by evaluating measurement models aimed at measuring the validity and reliability of variables in the research. The degree of validity and reliability can be seen through convergent validity, discriminant validity and construct reliability (Ghozali, 2008). The results of data processing to see the value of the load (loading) in order to test the convergent validity (convergent validity) of the research indicator is as contained in Table 2 below.

Table 2

Outer Loading Indicator

\begin{tabular}{|c|c|c|}
\hline Variable & Code & Outer Loading \\
\hline \multirow{4}{*}{ System Quality (X1) } & X11 & 0,773 \\
\cline { 2 - 3 } & X12 & 0,772 \\
\cline { 2 - 3 } & X13 & 0,715 \\
\cline { 2 - 3 } & X14 & 0,728 \\
\cline { 2 - 3 } & X15 & 0,771 \\
\hline \multirow{4}{*}{ Service Quality (X2) } & X21 & 0,965 \\
\cline { 2 - 3 } & X22 & 0,965 \\
\cline { 2 - 3 } & X23 & 0,965 \\
\cline { 2 - 3 } & X24 & 0,587 \\
\cline { 2 - 3 } & X25 & 0,587 \\
\hline User Satisfaction (Y1) & Y11 & 0,928 \\
\hline
\end{tabular}




\begin{tabular}{|c|c|c|}
\hline Variable & Code & Outer Loading \\
\hline & Y12 & 0,840 \\
\hline Learning Outcome (Net Benefit) (Y2) & Y21 & 1,000 \\
\hline
\end{tabular}

Source: Primary Data (processed)

In Table 2, it is seen that all research indicators have outer loading value of more than 0.50 which signifies that all indicators have qualified convergent validity. This means that all indicators used to measure research variables are declared valid (Ghozali, 2008). Furthermore, the results of data to test discriminant validity and composite reliability indicators or variables by looking at cronbach alpha, composite reliability and AVE values are as found in Table 3 below.

Table 3

\section{Cronbach Alpha, Composite Reliability dan AVE}

\begin{tabular}{|l|c|c|c|}
\hline \multicolumn{1}{|c|}{ Variable (Construct) } & Cronbach's Alpha & $\begin{array}{c}\text { Composite } \\
\text { Reliability }\end{array}$ & Nilai AVE \\
\hline System Quality (X1) & 0,817 & 0,867 & 0,566 \\
\hline Service Quality (X2) & 0,887 & 0,916 & 0,696 \\
\hline User Satisfaction (Y1) & 0,732 & 0,878 & 0,783 \\
\hline Learning Outcome (Net Benefit) (Y2) & 1,000 & 1,000 & 1,000 \\
\hline
\end{tabular}

Source: Primary Data (processed)

Based on Table 3, cronbach alpha and composite reliability values for all variables are greater than 0.6 and 0.70 as reference values, so it can be stated that all constructs have good reliability and are qualified. Table 3 also shows the AVE value of all variables greater than 0.5 , so that all constructs and indicators are declared valid (Ghozali, 2008).

\section{Structural Model Testing}

After the testing of the measurement model is done and the entire research construct is declared valid and reliable, the next stage is to test the structural model. It describes intervariable relationships based on substantive theory. Assessing structural models can be done by looking at structural models consisting of hypothesized relationships among variables in the research model. Using the Bootstrapping method in SmartPLS 3, the path coefficient, t-statistical values and Pvalues are obtained in Table 4 below.

Table 4

\section{Path Coefficient and t-Statistics}

\begin{tabular}{|l|c|c|c|}
\hline \multicolumn{1}{|c|}{ Influence Path } & Coefficient & t-statistics & $\begin{array}{c}\text { P- } \\
\text { values }\end{array}$ \\
\hline System Quality (X1) $\rightarrow$ User Satisfaction (Y1) & 0,439 & 3,852 & $\mathbf{0 , 0 0 0}$ \\
\hline Service Quality (X2) $\rightarrow$ User Satisfaction (Y1) & 0,354 & 2,325 & $\mathbf{0 , 0 2 0}$ \\
\hline $\begin{array}{l}\text { User Satisfaction (Y1) } \rightarrow \text { Learning Outcome (Net Benefit) } \\
(Y 2)\end{array}$ & 0,241 & 3,097 & $\mathbf{0 , 0 0 2}$ \\
\hline
\end{tabular}

Source: Primary Data (processed)

The t-table value is calculated in advance with the provisions of the alpha value $(\alpha)$ of 0.05 and the degree of freedom (df) of $n-2$. The amount of data used in this study is 163 , so the df value is 161 . The $t$-table value for $\mathrm{df}=161$, two tails, and $\alpha=0.05$ is 1.974 . Based on Table 4 , it is seen that all the $t$-statistical values in the table above are greater than the t-table values of 1,974. Thus, all independent variables have a significant influence on the dependent variables on the variable relationship paths on the model. Relationship paths on perception of System Quality (X1) $\rightarrow$ User Satisfaction (Y1), Quality of Service (X3) $\rightarrow$ User Satisfaction (Y1) and Perception of User 
Satisfaction (Y1) $\rightarrow$ Learning Outcomes (Net Benefit) (Y2) have significant relationship paths or influences.

While in the mediation role of user satisfaction variables (through the Specific Indirect Effects test in SmartPLS applications), based on Table 5, it is seen that user satisfaction variables can mediate the path of System Quality (X1) $\rightarrow$ User Satisfaction (Y1) $\rightarrow$ Learning Outcomes (Net Benefit) (Y2) and Service Quality (X2) $\rightarrow$ User Satisfaction (Y1) $\rightarrow$ Learning Outcomes (Net Benefit) (Y2) with a value of $t$-statistic above or greater than the t-table value.

Table 5

Mediating Role of User Satisfaction

\begin{tabular}{|l|c|c|c|}
\hline \multicolumn{1}{|c|}{ Influence Path } & Coefficient & t-statistics & $\begin{array}{c}\text { P- } \\
\text { values }\end{array}$ \\
\hline $\begin{array}{l}\text { System Quality (X1) } \rightarrow \text { User Satisfaction (Y1) } \rightarrow \text { Learning } \\
\text { Outcomes (Net Benefit) (Y2) }\end{array}$ & 0,106 & 2,062 & $\mathbf{0 , 0 4 0}$ \\
\hline $\begin{array}{l}\text { Service Quality (X2) } \rightarrow \text { User Satisfaction (Y1) } \rightarrow \text { Learning } \\
\text { Outcomes (Net Benefit) (Y2) }\end{array}$ & 0,085 & 1,970 & $\mathbf{0 , 0 4 9}$ \\
\hline
\end{tabular}

Source: Primary Data (processed)

In addition, the explanatory power of the model can be assessed by looking at the R-Square value of dependent variables. The results of data processing through Bootstrapping as in Table 6 below:

Table 6

R-Square $\left(\mathbf{R}^{2}\right)$

\begin{tabular}{|l|c|c|}
\hline \multicolumn{1}{|c|}{ Variable } & R-Square $\left(\boldsymbol{R}^{2}\right)$ & R-Square $\left(\boldsymbol{R}^{2}\right)$ Adjusted \\
\hline User Satisfaction (Y1) & 0,514 & 0,508 \\
\hline $\begin{array}{l}\text { Learning Outcomes (Net } \\
\text { Benefit) (Y2) }\end{array}$ & 0,058 & 0,052 \\
\hline
\end{tabular}

Source: Primary Data (processed)

Table 6 above shows that in the model, about 51.4\% (strong) of the variability (diversity) of total variables (constructs) perception of User Satisfaction (Y1) can be explained by its exogenous variables i.e. perceptions of System Quality (X1) and Service Quality (X2). That is, there is still about $48.6 \%$ of the diversity of these variables that can be explained from other factors such as the environment, organization, internet network and others. Meanwhile, about $5.80 \%$ (weak) of the variability (diversity) of total variables (construct) learning outcomes (Net Benefit) (Y2) can be explained by its exogenous variables consisting of perceptions of system quality (X1), service quality (X2), and user satisfaction (Y1).

\section{Discussion}

After going through several tests (tests) to assess or evaluate the measurement model (measurement model) against the reliability and validity of indicators and research variables in the form of convergent validity tests, discriminant validity, and composite reliability where all the results state that all indicators and waiting variables are valid and reliable, the next step is to test structural models ( structural models ). Structural model testing is conducted to look at the effect of system quality variables and service quality on user satisfaction and learning outcomes (net benefit) and mediation of user satisfaction variables in influencing the path of influence of system quality, information quality, and service quality on learning outcomes (net benefit), namely with the estimated value of structural path coefficients (estimate for path coefficients) and R-Square values (R2) of the research model. The path coefficient values to see the magnitude of influence 
(positive or negative) and the significance of each exogenous variable to the endogenous. While the value of R-Square (R2) indicates how much ability all exogenous variables have in explaining variations of their endogenous variables.

From the results of data processing using SmartPLS, obtained path coefficient values and tstatistical values and P-values to show their significance as in Table 4. In summary, Figure 3 below describes the PLS estimation model of the proposed research model.

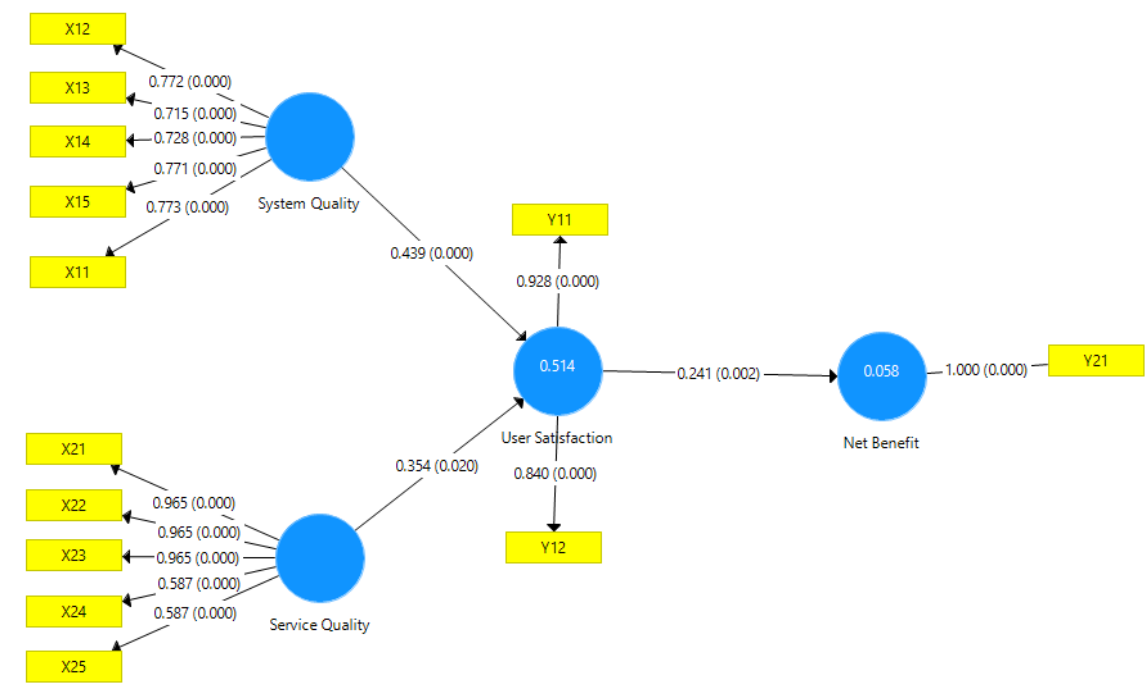

Figure 3

\section{Structural Model Testing Result (path coefficient dan p-values) Source: Primary Data (processed)}

Based on the results of hypothesis testing, both in Table 4 and Figure 3, all the results of the analysis support the proposed hypothesis in the direction of a positive relationship. System quality variables were found to have a positive and significant effect on user satisfaction and service quality was found to have a positive and significant effect on user satisfaction. In addition, user satisfaction variables were also found to have a positive and significant effect on learning outcomes (net benefit).

The first hypothesis (H1) states that system quality variables have a positive and significant effect on user satisfaction. The results of the analysis found that the system quality variable relationship to user satisfaction had a path coefficient value of 0.439 and a p-values of 0.000 . These results show that the path coefficient value is positive and the p-values are less than the $\alpha=0.05$. Based on these results it can be concluded that the quality of the system has a positive and significant influence on user satisfaction so that $\mathrm{H} 1$ is declared accepted.

The direction of positive influence, as indicated by the path coefficient value, means that the higher the quality of the system, the higher the user satisfaction of the distance learning system. Respondents' responses to the quality of learning systems can be empirically explained from the statements (suggestions and inputs) submitted in this research questionnaire. Users in this case trainees give a positive assessment of the quality of the learning system in an integrated manner. The results of this study indicate that the user's perception of the quality of the learning system with indicators such as: (1) the suitability of learning methods with PJJ material; (2) the adequacy of the time of PJJ implementation with the amount of material provided; and (3) adequacy of time in assignments, quizzes or exams; (4) the conformity of learning materials with the expectations/needs of participants; (5) Teaching materials are easy to understand, will increase user satisfaction of the system. These results support the success model of information systems by DeLone and McLean (2003) and previous research by Al-Azawei (2019) and Hidayatullah, et. al., (2020) which states 
that the quality of the system is one of the dimensions that determine the success of information systems. If the quality attributes of an information system built by an organization can meet what the user needs to complete the work, then the success of the implementation of the information system can be achieved.

From the results of the outer loading analysis in Table 2, the system quality indicator in the form of conformity of learning methods with distance learning materials, has the highest load value of 0.773 . This means that the suitability of learning methods with distance learning materials is perceived as the dominant factor that can affect trainee satisfaction. However, in the results of data collection through questionnaires in the open question (advice and input) section, some respondents stated that in some learning materials, the proportion of learning time is considered to still need to be added, especially to materials that require field practice or simulation directly. In general, participants complain about the implementation of training that is less effective if held remotely or online and should be held face-to-face (in person), as in CNT training, because this training is very important to see firsthand the types of narcotics.

The second hypothesis (H2) states that service quality variables have a positive and significant effect on user satisfaction. The relationship of service quality variables to user satisfaction has a path coefficient value of 0.354 and a t-statistics value of 2.325 . The results showed that the path coefficient value was positive with the $\mathrm{t}$-statistics value greater than the $\mathrm{t}$ table value $(1,974)$. In addition, the value of $p$-value is also known to be 0.020 or less than $\alpha=$ 0.05 . Based on these results, it can be concluded that the quality of service has a significant influence on user satisfaction so that $\mathrm{H} 2$ is declared accepted.

The direction of positive influence, as indicated by the path coefficient value, means that the higher the quality of the service, the higher the user satisfaction of the distance learning system. The results support the success model of information systems by DeLone and McLean (2003) and previous research by Hidayatullah, et. al., (2020) which states that the quality of service is one of the dimensions of information system success. From the results of the outer loading analysis in Table 2, service quality indicators in the form of: 1) the readiness of the organizer in serving participants during the PJJ process (responsiveness); (2) good attitude of the organizer in serving participants during the PJJ process (assurance); and (3) empathy from the service officer during the PJJ process (emphaty), has the highest load value of 0.965 . This means that the readiness of the organizer in serving participants during the PJJ process, the good attitude of the organizer in serving participants and empathy of the service officer, is perceived as the dominant factor that can affect the satisfaction of trainees.

The third hypothesis (H3) states that the variable of user satisfaction has a positive and significant effect on net benefit. The influence of user satisfaction variables on net benefits has a path coefficient value of 0.241 and a t-statistics value of 3.097. The results show that the path coefficient value is positive and the t-statistics value is greater than the t-table value $(1,974)$. In addition, the p-value is also known to be 0.002 or less than $\alpha=0.05$. Based on these results, it can be concluded that user satisfaction has a significant positive influence on net benefits so that $\mathrm{H} 3$ is declared accepted. The results of the hypothesis test showed that the user satisfaction variable had a positive effect on net benefit. The direction of positive influence, as indicated by the path coefficient value, means that the higher the user satisfaction, the higher net benefit in the form of learning outcome.

Respondents' responses to their satisfaction with distance learning system can be empirically explained by the statements submitted in this research questionnaire. User satisfaction in this study is the perception of trainees about satisfaction with the ease of learning facilities that are steamed with indicators such as: (1) satisfaction with accessible PJJ facilities/systems (system easiness); (2) satisfaction with facilities of PJJ systems that are easy to be used (overall satisfaction). The results of this study indicate that satisfaction with systems that meet the attributes of the system fit for need will contribute to the impact on individual performance or learning outcomes. These results support the information system success model by DeLone and McLean 
(2003) which states that user satisfaction and net benefits are dimensions in measuring information system success. The results support previous research conducted by Livari (2005), Noviyanti (2016) and Pambudi (2018) which stated that information system user satisfaction has a significant positive influence on the net benefits received from the system.

From the results of the load analysis in Table 2, the user satisfaction indicator in the form of ease of learning facilities, has a very high load value of 0.928 . This means that the indicator is perceived as the dominant factor that can affect the achievement of learning outcomes. However, in the results of data collection through questionnaires, some respondents complained of inadequate internet network quality in some areas that affected the implementation of learning.

Meanwhile, the fourth hypothesis (H4) states that user satisfaction mediates the influence of system quality variables on learning outcomes (net benefit). The results of the mediation test have a coefficient value of 0.106 and a t-statistics value of 2.062. The results showed that the value of the mediation coefficient was positive and the t-statistics value was greater than the t-table value $(1,974)$. In addition, the p-value is also known to be 0.040 or less than $\alpha=0.05$. Based on these results, it can be concluded that user satisfaction is able to mediate the influence of system quality variables on learning outcomes (net benefits) positively and significantly, so that $\mathrm{H} 4$ is declared accepted. This finding is in line with the results of research conducted by Iskandar and Amriani (2021) which found that user satisfaction can mediate and strengthen the effect of system quality on net manfat on SAKTI applications and Al Amin research (2014) which states that the performance of information users is influenced by variables in this study, namely the quality of information systems and user satisfaction both directly and indirectly with the mediation / intervening of melal. ui user satisfaction system that will affect its performance.

The fifth hypothesis (H5) states that user satisfaction mediates the effect of quality of service on learning outcomes (net benefit). The results of the mediation test have a coefficient value of 0.085 and a t-statistics value of 1,970 . The results showed that the value of the mediation coefficient was positive and the t-statistics value was greater than the t-table value $(1,974)$. In addition, the p-value is also known to be 0.049 or less than $\alpha=0.05$. Based on these results it can be concluded that user satisfaction is able to mediate the influence of service quality variables on learning outcomes (net benefit), so that H5 is declared accepted. These results are in line with the results of research conducted by Kadir, Ismail and Yatin (2015) which also found that user satisfaction was able to strengthen the influence of service quality on net benefits on the use of Enterprise Resources System (ERP) in one of the telecommunications industries in Malaysia.

\section{CONCLUSION}

Based on the results of analysis and testing it was concluded that the distance learning system synchronously and asynchronously through the KLC system (www.klc.kemenkeu.go.id) and Zoom Virtual Meeting at the Financial Education and Training Agency of Makassar proved empirically has run well and successfully based on indicators or approaches of the DeLone and McLean models. Of the five hypotheses proposed, all are proven and acceptable. The system quality has a positive and significant effect on user satisfaction, the service quality has a positive and significant effect on user satisfaction and user satisfaction also has a positive and significant effect on learning outcomes (net benefit). Meanwhile, user satisfaction can mediate the path of influence of system quality on learning outcomes (net benefit) and the influence of service quality on learning outcomes (net benefit). Based on this, the Financial Education and Training Agency of Makassar is expected to maintain and improve the quality of systems and services in the existing distance learning system in order to maintain and improve the satisfaction of trainees and learning outcomes.

\section{Limitation of the Study}


This research uses limited research objects, so it is recommended that in future research, observations and evaluations are carried out on a wider object involving various Financial Training Centers or work units within the Financial Education and Training Agency and expand the measurement of research variables such as environmental factors, organizations, internet networks and others, so that the results become a more comprehensive reference in policy formulation and development. $\mathrm{n}$ quality of apparatus resources. In addition, data collection is recommended using deeper interview methods in an effort to avoid the possibility of non-objective respondents in filling out questionnaires. Methods of calculation of variable mediation (intervening) used in subsequent research are suggested to use other methods, for example with causal step methods, product of coefficient methods or Sobel tests or others, in order to obtain a clearer and detailed picture of the difference in the results of each method used.

\section{REFERENCES}

Al Amin, M. (2014). Pengaruh Kualitas Informasi dan Kualitas Sistem Informasi Terhadap Kinerja Karyawan Dengan Mediasi Kepuasan Pengguna Sistem. Jurnal Analisis Bisnis Ekonomi, 12(1), 97-109.

Al-Azawei, A. (2019). What Drives Successful Social Media in Education and E-Learning? A Comparative Study on Facebook and Moodle. Journal of Information Technology Education, 18: 253-274.

Almutairi, H. (2001). Evaluating information system success in public organizations: a theoretical model and empirical validation. Disertasi Doktor, The Pennsylvania State University.

Bailey, J. E., \& Pearson, S. W. (1983). Development of a tool for measuring and analyzing computer user satisfaction. Management Science, 29(5), 530-545.

BPPK (Badan Pendidikan dan Pelatihan Keuangan). (2017). Peraturan Kepala BPPK Nomor PER-5/PP/2017 tentang Pedoman Evaluasi Pembelajaran di Lingkungan Kementerian Keuangan. Jakarta: BPPK.

BPPK (Badan Pendidikan dan Pelatihan Keuangan). (2020). Keputusan Kepala Badan Pendidikan dan Pelatihan Keuangan Nomor KEP-82 /PP/2020 Tentang Panduan Penyelenggaraan Pelatihan Jarak Jauh (Distance Learning) di Lingkungan Badan Pendidikan dan Pelatihan Keuangan. Jakarta: BPPK.

BPPK (Badan Pendidikan dan Pelatihan Keuangan). (2020). Kerangka Acuan Program Pelatihan. Jakarta: BPPK.

BPPK (Badan Pendidikan dan Pelatihan Keuangan). (2020). Majalah Edukasi Keuangan. 59, 6. Jakarta: BPPK.

Darmawan, E. (2018). Implementasi Model Pembelajaran Asynchronous Dalam Perancangan Aplikasi Simulasi Panduan Pecinta Alam Berbasis Android. Cloud Information, 3(2).

DeLone, W. H., \& McLean, E. R. (1992). Information systems success: The quest for the dependent variable. Information systems research, 3(1), 60-95.

Delone, W. H., \& McLean, E. R. (2003). The DeLone and McLean model of information systems success: a ten-year update. Journal of management information systems, 19(4), 9-30.

Elyas, A. H. (2018). Penggunaan Model Pembelajaran E-Learning Dalam Meningkatkan Kualitas Pembelajaran. Warta Dharmawangsa, 56.

Epriliyanti, Y. A., \& Ratnasari, V. (2020). Pemodelan Faktor-faktor yang Mempengaruhi Keefektifan Sistem Pembelajaran Daring (SPADA) Menggunakan Regresi Probit Biner (Studi Kasus: Mahasiswa ITS Masa Pandemi). Inferensi, 3(2), 115-122.

Fahirah, Puteri, S. L. E., \& Arnesia, P. D. (2020). Analisis Google Classroom Sebagai Sistem Pembelajaran Jarak Jauh Saat Pandemi Covid-19 Menggunakan Model Kesuksesan Sistem Informasi Delone Dan Mclean. Prosiding SeNTIK, 4(1), 57-64.

Ghozali, I. (2011). Analisis Applikasi Multivariate Dengan Program IBM SPSS 16. Semarang: Universitas Diponegoro. 
Goodhue, D. L. and Thompson, R. L. (1995). Task-technology fit and individualperformance. MIS Quarterly. vol. 19. 213-236.

Hamdi, M., \& Ismaryati, S. (2019). Materi Pokok Metodologi Penelitian Administrasi; 1-12; MAPU5103/4 SKS. Jakarta: Universitas Terbuka.

Hartono, J. (2011). Metodologi Penelitian Bisnis: Salah Kaprah dan Pengalaman-pengalaman. Yogyakarta: BPFE.

Hidayatullah, S., Khouroh, U., Windhyastiti, I., Patalo, R. G., \& Waris, A. (2020). Implementasi Model Kesuksesan Sistem Informasi DeLone And McLean Terhadap Sistem Pembelajaran Berbasis Aplikasi Zoom Di Saat Pandemi Covid-19. Jurnal Teknologi Dan Manajemen Informatika, 6(1), 44-52.

Iskandar, A., \& Amriani, T. N. (2021). DETERMINANT ANALYSIS OF THE NET BENEFITS OF THE USE OF SAKTI: USER SATISFACTION MEDIATION. International Journal of Economics, Business and Accounting Research (IJEBAR), 5(2).

Iskandar, A., \& Subekan, A. (2020). Evaluating The Distance Learning In The Pandemic Era: A Case Study At Financial Education And Training Agency Makassar. JURNAL PAJAR (Pendidikan Dan Pengajaran), 4(6), 1206-1221.

Ives, B., Olson, M., \& Baroudi, S. (1983). The Measurement of User Information Satisfaction. Communcations of the ACM.

Janson, M. A., dan Subramanian, A. (1996). Packaged software: Selection andImplementation Policies. INFOR 34(2), 133-151.

John, W. C. (2013). Research Design Pendekatan Kualitatif, Kuantitatif dan Mixed. Yogyakarta: Pustaka Pelajar.

Kadir, R. A., Ismail, N.A., \& Yatin, S. F. M. (2015). The benefits of implementing ERP system in telecommunications. Procedia-Social and Behavioral Sciences, 211, 1216-1222.

Livari, J. (2005). An empirical test of the DeLone-McLean model of information system success. ACM SIGMIS Database: the DATABASE for Advances in Information Systems, 36(2), 8-27.

Marlena, N., Dwijayanti, R., \& Edwar, M. (2018). Pengembangan Media Pembelajaran Multimedia Interaktif Berbasis Flash untuk Meningkatkan Hasil Belajar Mahasiswa. Jurnal Pendidikan Ekonomi dan Bisnis (JPEB), 6(1), 45-51.

Muharor, L. A., Busaini, B., \& Fitriah, N. (2015). Determinan Kesuksesan Aplikasi SIA Komdanas Pada Satuan Kerja Di Koordinator Wilayah Pengadilan Tinggi Mataram. InFestasi, 11(2), 151-170.

Nana, N., \& Surahman, E. (2019). Pengembangan Inovasi Pembelajaran Digital Menggunakan Model Blended POE2WE di Era Revolusi Industri 4.0. Prosiding SNFA (Seminar Nasional Fisika dan Aplikasinya), 4, 82-90.

Narayana, I. W. G. (2016). Analisis Terhadap Hasil Penggunaan Metode Pembelajaran Synchronous Dan Asynchronous. Semnasteknomedia Online, 4(1), 1-4.

Noviyanti. (2016). Mengukur kesuksesan Sistem Akuntansi Instansi Basis Akrual (SAIBA) menggunakan model DeLone \& Mclean. Jurnal Tata Kelola \& Akuntabilitas Keuangan Negara, 2(2), 151-173.

Nugroho, H. P., \& Lestyowati, J. (2020). Analisis Tingkat Kepuasan dan Kepentingan Pengguna Aplikasi SAKTI dengan PIECES Framework. Indonesian Treasury Review: Jurnal Perbendaharaan, Keuangan Negara Dan Kebijakan Publik, 5(2), 93-104.

Pambudi, K. H. (2018). Analisis Dimensi Kesuksesan Implementasi Sistem Aplikasi Keuangan Tingkat Instansi (Sakti) Pada Satuan Kerja Wilayah Provinsi Jawa Timur Dengan Pendekatan Delone And McLean Information System Success Model. Jurnal Ilmiah Mahasiswa FEB, 6(2).

Parasuraman, A., Zeithaml, V. A., \& Berry, L. L. (1988). Servqual: A multiple-item scale for measuring consumer perc. Journal of Retailing, 64(1), 12. 
Petter, S., DeLone, W., \& McLean, E. (2008). Measuring information systems success: models, dimensions, measures, and interrelationships. European journal of information systems, 17(3), 236-263.

Sari, N. L. (2020). Pelatihan Model Pembelajaran Jarak Jauh Berbasis Google Form Sebagai Media Pembela. KOMMAS: Jurnal Pengabdian Kepada Masyarakat, 1(2).

Sarwono, J. (2006). Metode penelitian kuantitatif dan kualitatif. Jakarta: Graha Ilmu.

Sarwono, J. (2006). Metode Penelitian Kuatitatif dan Kualitatif. Yogyakarta: Graha Ilmu.

Seddon P. B., \& Kiew M. Y. (1996). A partial test and development of DeLone and McLean's model of IS success. Australian Journal of Information Systems, 4(1), 90-109.

Seddon, P., \& Yip, S. K. (1992). An empirical evaluation of user information satisfaction (UIS) measures for use with general ledger accounting software. Journal of Information Systems, 6(1), 75-92.

Segars, A. H., \& Grover, V. (1993). Re-examining perceived ease of use and usefulness: A confirmatory factor analysis. MIS quarterly, 517-525.

Sekaran, U. (2006). Metodologi Penelitian untuk Bisnis. Buku I dan II. Edisi 4. Jakarta: Penerbit Salemba Empat.

Seksi Evaluasi dan Informasi, Balai Diklat Keuangan Makassar. (2020). Laporan Evaluasi PEnyelenggaran Diklat 2020. Makassar: Balai Diklat Keuangan Makassar.

Semantik BPPK. (2020). Sistem Manajemen Diklat dan Infromasi BPPK, Data Pelatihan Tahun 2020. https://semantik.bppk.kemenkeu.go.id/administrator/. Diakses tanggal 14 September 2021.

Septian, F. (2020). Pelatihan Pendidikan Jarak Jauh (PJJ) Berbantuan Media Sosial Edmodo. com bagi Guru SMP Terbuka Sawangan Depok. JAMAIKA: Jurnal Abdi Masyarakat, 1(2), 6068.

Silalahi U. (2009). Metode Penelitian Sosial. Jakarta: Rafika Aditama.

Syah, S., Angellia, F. (2020). Analisa Pemanfaatan Teknologi Daring Mahasiswa IBU Kosgoro 1957 Selama Pandemi Covid-19 Dengan Regresi Logistik Ordinal. JUNIF: Jurnal Nasioanl Informatika, 1(1): 43-56.

Widyaningsih, R. E. (2016). Peningkatan Kepuasan Pemakai Berbasis Kualitas Sistem Dan Kualitas Informasi Terhadap Net Benefit studi pada Bank BPD Jawa Tengah Kota Semarang (Doctoral dissertation, UNIKA SOEGIJAPRANATA).

Wiyono, Adrianto S., Hartono, Jogiyanto, Ancok, Djamaludin. (2008). Aspek Psikologis pada Implementasi Sistem Teknologi Informasi. Makalah dalam Seminar e-Indonesia Initiative 2008 (eII2008), Konferensi dan Temu Nasional Teknologi Informasi dan Komunikasi untuk Indonesia. Jakarta.

Yakubu, M. N., \& Dasuki, S. (2018). Assessing eLearning systems success in Nigeria: An application of the DeLone and McLean information systems success model. Journal of Information Technology Education: Research, 17, 183-203.

Yang, X.-P., Liu, X.-X., Guo, Y.-H., \& Wang, S.-J. (2012). Optimization and Application of Multimedia Teaching Means of Specialized Courses in Engineering. Energy Procedia, 17, $1878-1884$.

Yulianto, W. (2020). Implementasi Sistem Pelatihan E-Learning Terhadap Kepuasan Pegawai Kementerian Kelautan Dan Perikanan Melalui Aplikasi E-Milea. Eqien: Jurnal Ekonomi dan Bisnis, 7(2), 107-116. 